\title{
CrimRxiv
}

\section{Making Things Stick: Surveillance Technologies and Mexico's War on Crime}

Keith Guzik

Published on: Mar 04, 2022

DOI: $10.21428 / \mathrm{cb} 6 \mathrm{ab} 371 . \mathrm{fb} 08 \mathrm{f} 431$

License: Creative Commons Attribution 4.0 International License (CC-BY 4.0). 
